Check for updates

Cite this: RSC Adv., 2019, 9, 26609

\title{
Interactions between marmatite and bornite during the oxidative dissolution process in abiotic and biotic systems $\uparrow$
}

\begin{abstract}
Yanjun Zhang, (D) ab Hongbo Zhao, (D) *ab Yisheng Zhang, ${ }^{\text {ab }}$ Lu Qian, ${ }^{\text {ab }}$ Luyuan Zhang, $^{\text {ab }}$ Xiaoyu Meng, ${ }^{\text {ab }}$ Xin Lv, ${ }^{\text {ab }}$ Abhilash, ${ }^{c}$ Hussnain Ahned Janjua (D) d and Guanzhou Qiu ${ }^{\text {ab }}$

Marmatite and bornite are commonly associated together in nature, and their interactions in an acidic environment are vital for both (bio)hydrometallurgy and acid mine drainage (AMD) production. In this work, dissolution experiments (marmatite : bornite $=2: 0,3: 1,1: 1,1: 3$ and $0: 2$ ) accompanied by analytic techniques such as electrochemical methods, Raman spectroscopy and synchrotron radiationXRD (SR-XRD) were utilized to interpret the interactions between marmatite and bornite in acidic abiotic and biotic systems. The dissolution experiments showed that marmatite can significantly accelerate the oxidative dissolution of bornite, especially in the abiotic system. On the contrary, bornite inhibited the oxidative dissolution of marmatite when the percentage of bornite was high. Electrochemical measurements proved that the galvanic interactions between marmatite and bornite were slight and should not be the main cause for the interactions. Combined with the dissolution experiments, analytic techniques and previous references, it could be speculated that marmatite accelerated bornite dissolution mainly by providing an iron source, which acted as the energy source for microorganisms and oxidants. Bornite affected the dissolution of marmatite mainly by $\mathrm{Cu}^{2+}$ ions dissolving from bornite. Bornite inhibited the oxidative dissolution of marmatite mainly because a high $\mathrm{Cu}^{2+}$ concentration could significantly hinder marmatite dissolution. In addition, the formation of elemental sulfur or jarosite was also one important cause. Bornite intensified marmatite dissolution when the percentage of bornite or the $\mathrm{Cu}^{2+}$ concentration was extremely low and then, a synergic dissolution process occurred.
\end{abstract}

Received 15th May 2019

Accepted 28th July 2019

DOI: $10.1039 / c 9 r a 03658 j$

rsc.li/rsc-advances

\section{Introduction}

Acid mine drainage (AMD) is primarily derived from mining tailings, rock pile-ups, and oxidation of pyrite and other sulfide minerals. ${ }^{1-3}$ It has caused serious environmental problems. AMD has extremely low $\mathrm{pH}$ values, which lead to the dissolution of some minerals and the release of metal ions such as cupric, ferric, zinc, and nickel ions into the solution. Heavy metal ions and the acidity of the solution contaminate the surrounding groundwater layer. Its production, release, movement and attenuation are conducted in accordance with complex physical, chemical and biological factors. Although the chemistry of AMD generation is straightforward, the final product is

${ }^{a}$ School of Minerals Processing \& Bioengineering, Central South University, No. 932 Lushan South Road, Yuelu District, Changsha, Hunan, China, 410083. E-mail: alexandercsu@126.com; zhbalexander@csu.edu.cn

${ }^{b}$ Key Lab of Biohydrometallurgy of Ministry of Education, Changsha, Hunan, China ${ }^{c}$ CSIR - National Metallurgical Laboratory, Jamshedpur 831007, India

${ }^{d}$ Atta-ur-Rahman School of Applied Biosciences, National University of Sciences and Technology (NUST), Sector H-12, Islamabad, Pakistan

$\dagger$ Electronic supplementary information (ESI) available. See DOI: 10.1039/c9ra03658j a function of the geology of the mining region, presence of microorganisms, temperature and also the availability of water and oxygen. ${ }^{4}$ Recent advances concentrate more on the development of treatment techniques involved in source control and migration control. ${ }^{5}$ Source control is an effective method that directly controls the formation of AMD by avoiding direct contact between oxygen or water and sulfide minerals..$^{6,7}$

Bio-dissolution or bacterial dissolution refers to the process of using some bacteria's oxidizing activities to dissolve metal sulfide minerals. ${ }^{8}$ It has been successfully implemented to extract secondary copper sulfide minerals. ${ }^{\mathbf{9 , 1 0}}$ There are many bioleaching microorganisms such as A. ferrooxidans, L. ferrooxidans, Acidithiobacillus caldus (A. caldus), and Sulfobacillus thermosulfidooxidans ( $S$. thermosulfidooxidans). A. ferrooxidans is one of the most commonly used species in bio-dissolution or biomineralization; it is frequently observed in nature and is present in sulfide minerals such as pyrite, coal mines, and also in acid mine drainage. ${ }^{11-13}$ It is a Gram-negative and chemoautotrophy bacterium, which fixes carbon dioxide in the air as a carbon source. Furthermore, it can oxidize ferrous ions and reduce sulfides as energy sources. ${ }^{\mathbf{1 4}}$

Bornite $\left(\mathrm{Cu}_{5} \mathrm{FeS}_{4}\right)$ is an extremely important copper sulfide mineral. It is commonly found in the earth with other sulfide 
minerals. The economic benefit of bornite ranks third among copper sulfide ores and second only to chalcopyrite and chalcocite. ${ }^{15}$ The chemical and biological oxidation of bornite is relatively fast and easy; also, residual bornite was not detected by X-ray diffraction in solids after 2 days of contact in an acid solution and virtually, $100 \%$ of copper solubilization was achieved in A. ferrooxidans cultures with or without ferrous ions. ${ }^{\mathbf{1 6}}$ Theoretically, the sum of the number of iron and zinc atoms in marmatite is similar to the number of sulfur atoms. Therefore, the chemical formula of marmatite can be approximately regarded as $\left(\mathrm{Zn}_{1-x} \mathrm{Fe}_{x}\right) \mathrm{S}$, and it is one of the most important zinc containing resources. Marmatite is formed by replacing some zinc sites in sphalerite (ZnS) crystals with iron elements, and the iron contents are about $6-25 \% .{ }^{17}$ According to the percentage of iron elements, it can be categorized into low-iron marmatite, medium-iron marmatite and high-iron marmatite. Marmatite is analogous to bornite and often coexists with other sulfide minerals such as chalcopyrite, pyrite and bornite. On account of the relatively low zinc content in marmatite, it is difficult to effectively treat with conventional techniques. ${ }^{18}$ Nevertheless, as a result of the presence of iron, it has a faster oxidation dissolution rate than sphalerite. ${ }^{\mathbf{1 9}}$ Therefore, it is more suitable for bio-dissolution. ${ }^{20-22}$

Some recent studies have shown the interactions of different sulfide minerals in sulfuric acid and also in the presence of bacteria. Zhao et al. ${ }^{23}$ reported that bornite decreased the oxidation reduction potential (ORP) and maintained it at an appropriate range $(380-480 \mathrm{mV}$ vs. $\mathrm{Ag} / \mathrm{AgCl})$ to promote chalcopyrite (A) dissolution; however, this caused the redox potential to be out of the optimum range and inhibited chalcopyrite (B) dissolution in the presence of L. ferriphilum. However, they suggested that a synergistic effect existed between chalcopyrite and bornite during bioleaching in the presence of A. ferrooxidans. ${ }^{24}$ R. G. Acres et al. ${ }^{25}$ proposed that in the presence of hydrochloric acid, bornite can decrease the oxidation rate of chalcopyrite, thus resulting in the slow dissolution of chalcopyrite. Saavedra et al. ${ }^{26}$ suggested that $\mathrm{CuFeS}_{2}$ and $\mathrm{Fe}_{3} \mathrm{O}_{4}$ behaved as an anode and a cathode, respectively, in a natural mixed mineral, thus stimulating and increasing the chalcopyrite reactivity and preventing the formation of a passive layer commonly formed during chalcopyrite oxidation in both the sterile and L. ferriphilum systems. Liao et al. ${ }^{27}$ investigated the effect of marmatite on the bioleaching of chalcopyrite and observed that marmatite hindered the dissolution of chalcopyrite. The reason for this finding may be that the redox potential of the mixed minerals was not in the optimum range.

In a natural environment, the contact of sulfide minerals cannot be avoided. Thus, it is essential to study the interaction of sulfide minerals in a geochemical environment. Both marmatite and bornite are iron-bearing sulfide minerals, but their interactions in an acidic environment have not been studied yet. However, the use of bacteria for the bio-dissolution of flotation marmatite concentrates and bornite has been proven to be feasible. ${ }^{\mathbf{2 8}, 29}$ Therefore, the dissolution processes of marmatite and bornite in the abiotic system and in the presence of A. ferrooxidans were conducted in this work. Analytic techniques such as electrochemical experiments, synchrotron radiation
XRD (SR-XRD) and Raman spectroscopy were conducted to provide some insights into the interaction mechanisms between marmatite and bornite during the mixed dissolution process in the acidic abiotic and biotic systems. This would be useful for the research fields of both (bio)hydrometallurgy and AMD. On the one hand, pyrite is the main cause of AMD production, but other sulfide minerals such as zinc sulfide and copper sulfide can also release heavy metal ions and contribute to the production of AMD, resulting in serious environmental problems. ${ }^{30,31}$ Therefore, the interaction between them plays an important role in understanding the mechanism of AMD production and would also provide a reference for preventing the production of AMD from the source. On the other hand, bornite $\left(\mathrm{Cu}_{5} \mathrm{FeS}_{4}\right)$ and chalcopyrite $\left(\mathrm{CuFeS}_{2}\right)$ are the most abundant copper mineral resources in the world as both usually co-exist in raw ores. ${ }^{32}$ Moreover, studies have shown that chalcopyrite is reduced to bornite in the initial stage of bioleaching, which is also the rate-limiting step in the dissolution of chalcopyrite since the dissolution of bornite is very rapid. ${ }^{33,34}$ As stated in several recent reports, R. G. Acres et al. ${ }^{25}$ found that bornite can reduce the oxidation rate of chalcopyrite. However, Zhao et $a .^{24}$ proposed that a synergistic effect existed between chalcopyrite and bornite bioleaching in the presence of A. ferrooxidans. Therefore, this work plays an important role in understanding the biological leaching behaviors of mixed ores and the dissolution mechanism of other copper sulfide ores, especially chalcopyrite, which represents approximately $70 \%$ of the known copper reserves; ${ }^{35}$ this also provides an important research example for hydrometallurgy.

\section{Experimental section}

\subsection{Dissolution experiments}

2.1.1. Pretreatment of experimental materials. The bornite mineral was obtained from the geological museum of Guangxi Province of China, and the marmatite mineral was obtained from Dachang Mine of Guangxi Province of China. These minerals (bornite and marmatite) were of high purity with $>90 \%$ wt $\%$ purity using powder X-ray fluorescence (XRF). Please see the ESI Table $\mathrm{S} 1 \uparrow$ for element composition. Minerals were ground to achieve an adequate degree of liberation with particles sizes of 200 meshes $(-0.074 \mathrm{~mm})$ for experiments. ${ }^{36,37}$ The $9 \mathrm{~K}$ medium and deionized water used in the experiments were sterilized at $121{ }^{\circ} \mathrm{C}$ for 20 minutes by a high-pressure steam sterilizer. The composition of the $9 \mathrm{~K}$ medium and the culture of the strains are provided in a previous study. ${ }^{24,38}$ For the growth of bacteria, $\mathrm{FeSO}_{4} \cdot 7 \mathrm{H}_{2} \mathrm{O}\left(44.70 \mathrm{~g} \mathrm{~L}^{-1}\right)$ was dissolved in deionized water and filtrated for sterilization through a $0.22 \mu \mathrm{m}$ filter. The two mineral samples were sterilized under an ultraviolet lamp for 20 minutes.

2.1.2. Incubation experiments of $A$. ferrooxidans. A. ferrooxidans used in this work was provided by the Key Lab of Biohydrometallurgy of Ministry of Education, Central South University. The strains were cultured in a $9 \mathrm{~K}$ medium at the temperature of $30{ }^{\circ} \mathrm{C}$ and a $\mathrm{pH}$ of $1.70-1.80$ at a rotation speed of $170 \mathrm{rpm}$ for 5 days prior to the bio-dissolution experiments. $\mathrm{FeSO}_{4} \cdot 7 \mathrm{H}_{2} \mathrm{O}\left(44.70 \mathrm{~g} \mathrm{~L}^{-1}\right)$ was used as the energy source. 
Microorganism cells were collected from the bacteria solution in the logarithmic phase by centrifugation $\left(10^{4} \mathrm{rpm}\right.$ and $25^{\circ} \mathrm{C}$ for 15 minutes) when the cell concentration was higher than 1.0 $\times 10^{7}$ cells per $\mathrm{mL}$; then, the bacteria that adhered on the centrifuge bottle wall were rinsed with $1 \mathrm{~mL}$ sterilized distilled water. Lastly, the bacteria were collected for bio-dissolution experiments. In the process of counting bacteria, we diluted the bacteria solution by a certain amount. Afterward, the sample was added to the hemocytometer for microscopic examination by a bright-field microscope; this process was repeated three times and then, we obtained the average values. Finally, the bacterial concentration was calculated according to the formula: the number of bacteria $=$ the average number of each cell $\times 400 \times 10000 \times$ the dilution ratio.

2.1.3. Dissolution of minerals. The dissolution experiment was divided into two batches. The first batch of dissolution experiments with marmatite and bornite at different mass ratios (marmatite : bornite $=2: 0,3: 1,1: 1,1: 3$ and $0: 2$ ) was conducted in $250 \mathrm{~mL}$ flasks containing $99 \mathrm{~mL}$ sterilized $9 \mathrm{~K}$ basal medium and $1 \mathrm{~mL}$ bacteria culture. In order to investigate the effect of $\mathrm{Cu}^{2+}$ on the dissolution of marmatite, we conducted a second batch of dissolution experiments. Similarly, a series of concentration gradients of $\mathrm{Cu}^{2+}(0,0.01,0.05,0.25,0.5,0.75,1.0$ and $2.5 \mathrm{~g} \mathrm{~L}^{-1}$ ) were conducted in $250 \mathrm{~mL}$ flasks containing $100 \mathrm{~mL}$ sterilized $9 \mathrm{~K}$ basal medium and $2 \mathrm{~g}$ marmatite. Then, all dissolution experiments were conducted at $30{ }^{\circ} \mathrm{C}$ and $170 \mathrm{rpm}$ in an orbital shaker for 14 days. Water evaporation was compensated for by adding sterilized deionized water periodically. During the testing period, the liquid sample loss was supplemented with the same amount of distilled water, and the values of $\mathrm{pH}$ were maintained at $1.7-1.80$ by adding sulfuric acid. During the dissolution process, the variations in $\mathrm{pH}, \mathrm{ORP}$ and bacterial concentrations, and cupric, iron and zinc ion concentration values were measured.

\subsection{Electrochemical experiments}

The electrodes used in all electrochemical experiments were carbon paste electroactive electrodes (CPEEs). The composition was $0.7 \mathrm{~g}$ minerals, $0.2 \mathrm{~g}$ graphite, and $0.1 \mathrm{~g}$ solid paraffin. The mixtures were manually homogenized, and they were mechanically pressed at 20 tons to obtain a uniform sample surface. ${ }^{39}$ All the experiments were performed with a three-electrode system with the graphite rod as the counter electrode and the $\mathrm{Ag} / \mathrm{AgCl}$ (using $3.0 \mathrm{~mol} \mathrm{~L}^{-1} \mathrm{KCl}$ ) electrode as the reference electrode. The open circuit potential (OCP), Tafel tests and cyclic voltammetry tests of bornite, marmatite and the mixed minerals with different ratios of marmatite and bornite were performed at the electrochemical work station. Meanwhile, the galvanic current effect between marmatite and bornite was measured. Prior to each test, the corresponding electrodes were smoothed by 1200 mesh sandpapers. The electrolyte was deionized water with $\mathrm{pH}$ of 1.70. During the test, nitrogen was introduced into the electrolyte to remove oxygen. OCP was conducted for 900 seconds. Tafel tests were performed at a sweep rate of $2 \mathrm{mV} \mathrm{s}^{-1}$. Cyclic voltammetry (CV) tests were conducted at a sweep rate of $20 \mathrm{mV} \mathrm{s}^{-1}$. The galvanic current between marmatite and bornite was analyzed by an electrochemical noise measurement program for $900 \mathrm{~s}$.

\subsection{Analysis of liquid and solid samples}

The analytic process for the liquid sample during the (bio) dissolution process is shown in Fig. 1a. The dissolved $\mathrm{Fe}^{2+}$ and $\mathrm{Fe}^{3+}$ were quantified through the $o$-phenanthroline spectrophotometry method ${ }^{\mathbf{4 0}}$ with a microplate reader (BOX 998, Biotek Instruments, HIGHLAND PARK, USA). Iron, $\mathrm{Cu}^{2+}$, and $\mathrm{Zn}^{2+}$ concentrations were analyzed by inductively coupled plasmaatomic emission spectrometry (ICP-AES) (ICAP-7400 Radial, Thermo Fisher Scientific, MA, USA); meanwhile, the $\mathrm{pH}$ and oxidation-reduction potential (ORP) values were monitored with a $\mathrm{pH}$ meter (PHSJ-4A, Shanghai LEICI Co., Shanghai, China) and ORP meter (BPH-221, Dalian BELL Co., Dalian, China), respectively. The bacterial density was detected using a hemocytometer in a bright field microscope (CX31RTSF, Tokyo OLYMPUS Co., Tokyo, Japan). The mineralogical contents of bornite and marmatite were detected by XRF (Axios MAX, PANalytical B.V., Almelo, Holland). All electrochemical experiments were performed by electrochemical TAB (CHI700E, Shanghai $\mathrm{CH}$ Instruments, Shanghai, China). The mineralogical phases of bornite, marmatite and the residues were analyzed by SR-XRD at beam line of 4B9A of the Beijing Synchrotron Radiation Facility (BSRF). The mineralogical changes were detected by a confocal micro-Raman spectrometer (inVia Qontor, Renishaw, United Kingdom).

\section{Results and discussion}

\subsection{Results}

3.1.1. Dissolution experiments. Fig. 1b-e present the metal ion extractions of mineral samples in the abiotic and biotic ( $A$. ferrooxidans) systems. The interactions between bornite and marmatite in the abiotic system were more obvious compared to those in the biotic system. The copper extraction remarkably increased on increasing the ratio of marmatite, indicating that the addition of marmatite promoted the dissolution of bornite in the abiotic system. With the addition of bornite, the zinc extraction of marmatite decreased obviously, proving that the addition of bornite hindered the dissolution of marmatite. However, the amount of bornite seemed to have a negligible effect on hindering marmatite dissolution (marmatite : bornite $=3: 1,1: 1$ and $1: 3$ ).

In the presence of $A$. ferrooxidans, the interactions between bornite and marmatite were similar to those in the abiotic system. The addition of marmatite accelerated the dissolution of bornite, but the final copper extractions of single bornite and mixed ores were not very different; all resulted in the final copper extraction of more than $90 \%$. On the contrary, the addition of bornite inhibited the dissolution of marmatite but eventually, the zinc extraction of single marmatite and mixed ores reached higher than $90 \%$.

The effect of cupric ions on the oxidative dissolution of marmatite is shown in Fig. 1e. The concentrations of cupric ions were $0,0.01,0.05,0.25,0.5,0.75,1.0$ and $2.5 \mathrm{~g} \mathrm{~L}^{-1}$; the 
(a)
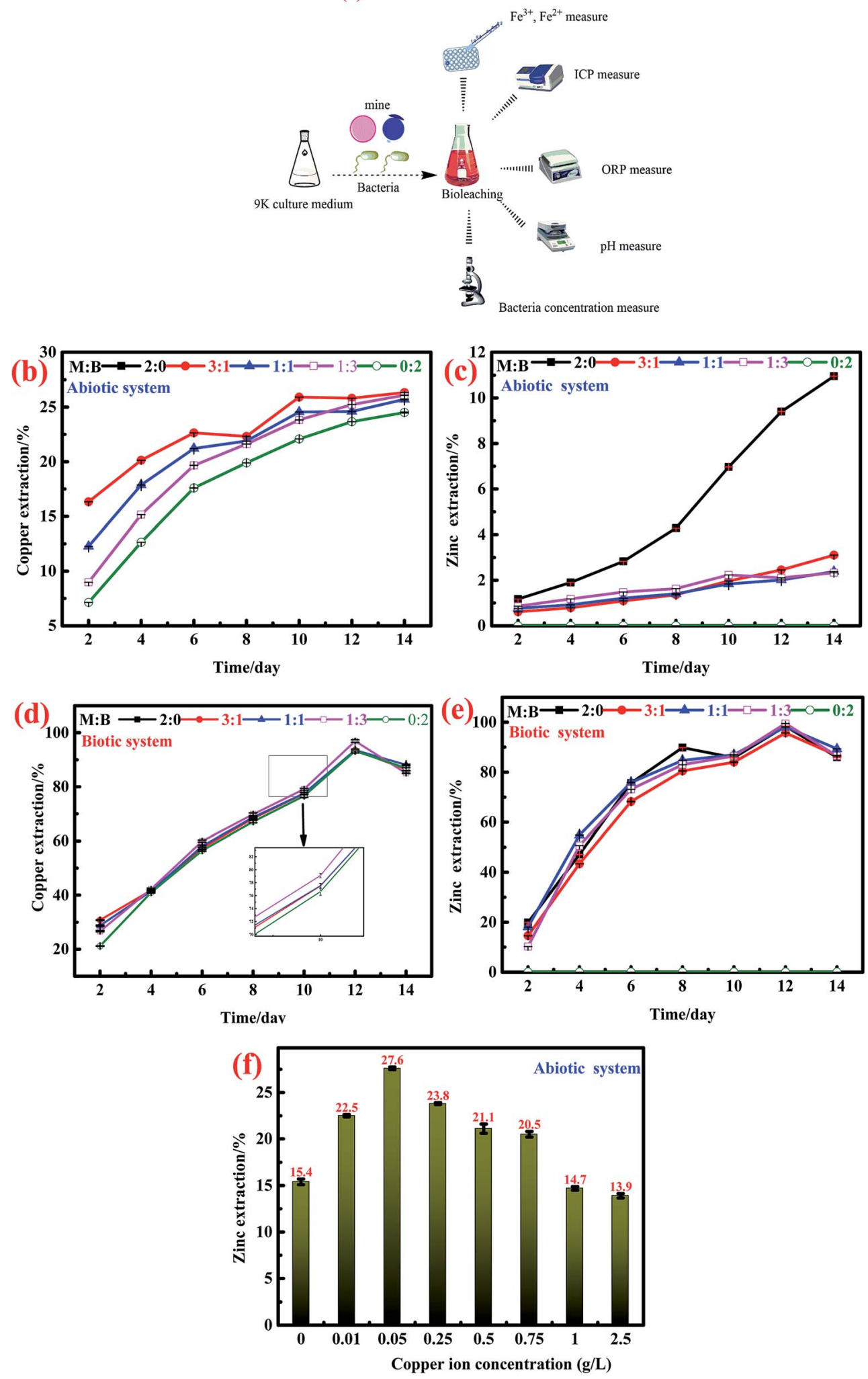

Fig. 1 The dissolution behaviors of marmatite and bornite with different mass ratios in the absence and presence of bacteria. (a) Model diagram of the liquid sample detection during dissolution experiments. The ion extraction of copper and zinc in the absence of bacteria: (b) copper extraction and (c) zinc extraction. The ion extraction of copper and zinc in the presence of bacteria: (d) copper extraction and (e) zinc extraction. (f) The final zinc extractions of marmatite under different conditions of $\mathrm{Cu}^{2+}$ concentrations. M (marmatite) and $\mathrm{B}$ (bornite). 
corresponding final zinc extraction values of marmatite were $15.4,22.5,27.6,23.7,21.1,20.5,14.6$ and $13.9 \%$. It could be found that the cupric ion concentration of $0-0.75 \mathrm{~g} \mathrm{~L}^{-1}$ accelerated the dissolution of marmatite. However, the cupric ions could obviously hinder the dissolution of marmatite when their concentration exceeded $1.0 \mathrm{~g} \mathrm{~L}^{-1}$, which was consistent with previous research. ${ }^{41}$

\subsubsection{Electrochemical experiments}

3.1.2.1. Open circuit potential and galvanic current effect test. OCP is an important reference for judging the presence of the galvanic current between different minerals. The OCP values for the minerals consisting different ratios of marmatite and bornite were 153 (2:0), $213(3: 1), 216(1: 1), 226(1: 3)$ and 242 $(0: 2) \mathrm{mV}$ (Fig. 2a). The OCP value for mixed sulfides was higher than that of single marmatite, and it increased as the proportion of bornite increased gradually.

Theoretically, there is a galvanic current between marmatite and bornite. In the galvanic couple of marmatite-bornite, bornite would act as the cathode, marmatite would act as the anode, and the oxidation of marmatite would be accelerated. However, this conjecture was contrary to the results of the dissolution experiments. The electrochemical noise measurement results further proved that the galvanic current between marmatite and bornite was extremely weak (Fig. 2b). Hence, the galvanic effect between bornite and marmatite was extremely small and could be ignored.

3.1.2.2. Tafel studies. The corrosion current density indicates the kinetics for corrosion reactions. The higher the corrosion current, the faster the reaction rate. The corrosion potential indicates the thermodynamics for the degree of corrosion. A high corrosion potential means that it is difficult for the corrosion reaction to occur, and a low corrosion potential indicates that the reaction can take place easily. Fig. 2c shows the Tafel plots of the electrodes with different mass ratios of marmatite and bornite. The result calculated from the Tafel plot showed that the corrosion current densities of the samples containing different ratios of marmatite and bornite were 8.122 $\times 10^{-3}(2: 0), 1.785 \times 10^{-1}(3: 1), 2.103 \times 10^{-1}(1: 1), 2.018 \times$ $10^{-1}(1: 3)$, and $2.972 \times 10^{-1}(0: 2) \mathrm{mA} \mathrm{cm}^{-2}$; the corresponding corrosion potentials were 208.5, 307.1, 294.2, 305.2 and $316.9 \mathrm{mV}$.

Fig. $2 d$ indicates the oxidation and reduction reactions for the samples with different mass ratios of marmatite and bornite. The cyclic voltammetry curves of the mixed ores and single minerals were similar; they showed four anodic peaks (1-4) and two cathodic peaks 5 and 6). Therefore, the electrochemical interactions did not change the redox reactions of bornite and/or marmatite but did change the reaction kinetics.
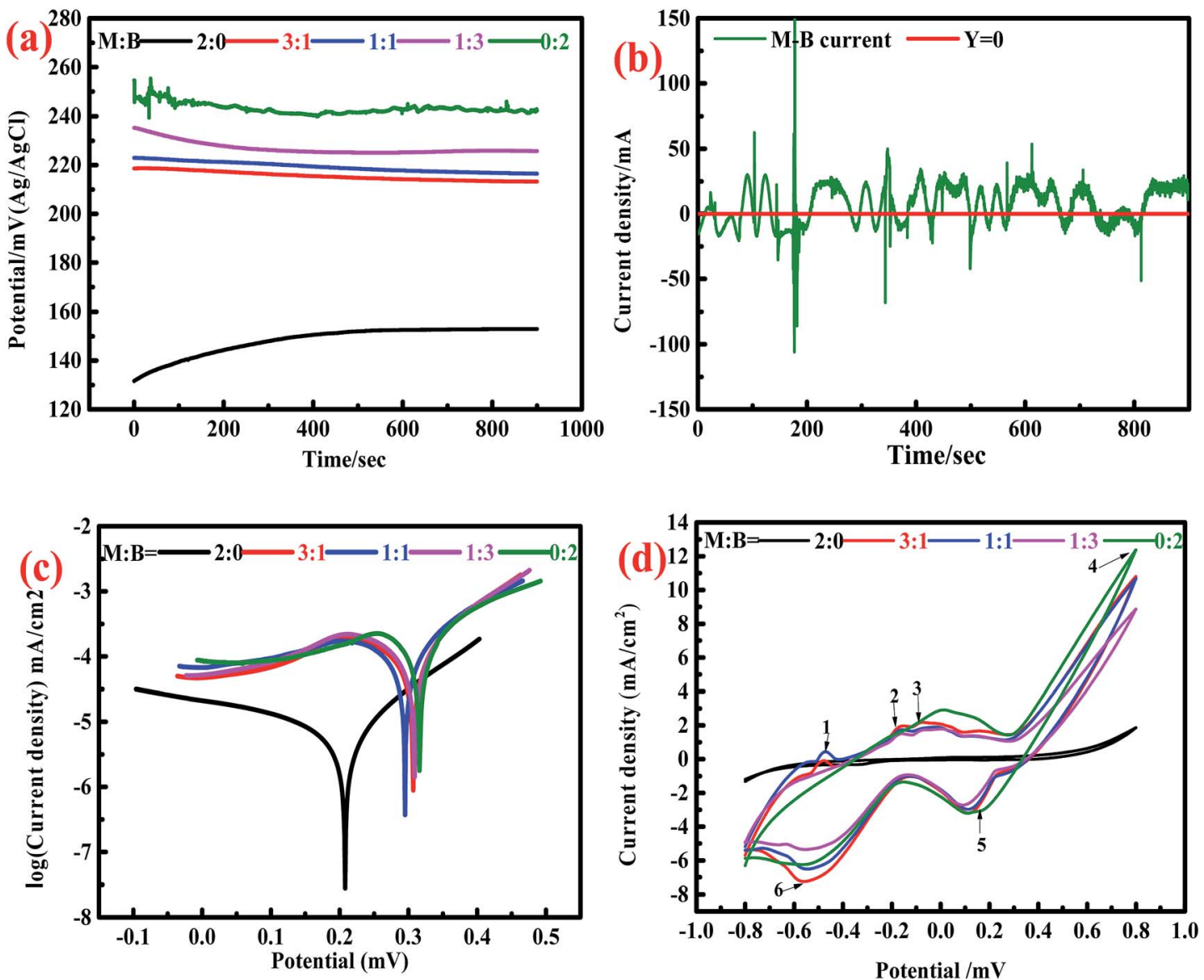

Fig. 2 Comparison of the electrochemistry of electrodes with different mass ratios of marmatite and bornite: (a) open circuit potential, (b) galvanic current, (c) Tafel plots, (d) cyclic voltammograms; M (marmatite) and B (bornite). 
The dissolution reactions for marmatite and bornite can be summarized as follows in eqn (1)-(3): ${ }^{16,42}$

$\mathrm{Zn}_{(1-x)} \mathrm{Fe}_{x} \mathrm{~S}+2 \mathrm{H}^{+}+1 / 2 \mathrm{O}_{2} \rightarrow(1-x) \mathrm{Zn}^{2+} y \mathrm{Fe}^{2+}+(x-y) \mathrm{FeS}+$ $(1-x+y) \mathrm{S}+\mathrm{H}_{2} \mathrm{O}$

$\mathrm{Zn}_{(1-x)} \mathrm{Fe}_{x} \mathrm{~S}+2(1-x+y) \mathrm{Fe}^{3+} \rightarrow(1-x) \mathrm{Zn}^{2+}+(2-2 x+3 y)$

$\mathrm{Fe}^{2+}+(x-y) \mathrm{FeS}+(1-x+y) \mathrm{S}$

$4 \mathrm{Cu}_{5} \mathrm{FeS}_{4}+37 \mathrm{O}_{2}+20 \mathrm{H}^{+} \rightarrow 20 \mathrm{Cu}^{2+}+4 \mathrm{Fe}^{3+} 16 \mathrm{SO}_{4}^{2-}+10 \mathrm{H}_{2} \mathrm{O}(3)$

Peak 1 was attributed to the oxidation reaction of metal copper to chalcocite $\left(\mathrm{Cu}_{2} \mathrm{~S}\right)$; the reaction is summarized in eqn (4): ${ }^{\mathbf{3 4 4 3 , 4 4}}$

$$
2 \mathrm{Cu}^{0}+\mathrm{H}_{2} \mathrm{~S} \rightarrow \mathrm{Cu}_{2} \mathrm{~S}+2 \mathrm{H}^{+}+2 \mathrm{e}^{-}
$$

The reaction of peak 2 and may be the formation of the sulfur element as well as the reaction formula can be seen in eqn (5): $:^{\mathbf{4 5 , 4 6}}$

$$
\mathrm{H}_{2} \mathrm{~S} \rightarrow \mathrm{S}^{0}+2 \mathrm{H}^{+}+2 \mathrm{e}^{-}
$$

Peak 3 and 4 represent the stepwise oxidation of chalcocite. A large peak $\mathrm{d}$ was detected at about $600-800 \mathrm{mV}$. The reactions for the formation of chalcocite through a series of defect sulfides djurleite $\left(\mathrm{Cu}_{1.92} \mathrm{~S}\right)$, digenite $\left(\mathrm{Cu}_{1.60} \mathrm{~S}\right)$ and covellite (CuS) are shown in eqn (6)-(8): $:^{38,44,47}$

$$
\begin{gathered}
\mathrm{Cu}_{2} \mathrm{~S} \rightarrow \mathrm{Cu}_{1.92} \mathrm{~S}+0.08 \mathrm{Cu}^{2+}+0.16 \mathrm{e}^{-} \\
\mathrm{Cu}_{1.92} \mathrm{~S} \rightarrow \mathrm{Cu}_{1.60} \mathrm{~S}+0.32 \mathrm{Cu}^{2+}+0.64 \mathrm{e}^{-} \\
\mathrm{Cu}_{1.60} \mathrm{~S} \rightarrow \mathrm{CuS}+0.60 \mathrm{Cu}^{2+}+1.2 \mathrm{e}^{-}
\end{gathered}
$$

The cathodic peak 5 may represent the reduction reactions of elemental sulfur, chalcocite and bornite; the reactions are shown in eqn (9)-(11): ${ }^{\mathbf{4 3 , 4 4 , 4 7}}$

$$
\begin{gathered}
\mathrm{S}^{0}+2 \mathrm{H}^{+}+2 \mathrm{e}^{-} \rightarrow \mathrm{H}_{2} \mathrm{~S} \\
\mathrm{Cu}_{2} \mathrm{~S}+2 \mathrm{H}^{+}+2 \mathrm{e}^{-} \rightarrow 2 \mathrm{Cu}^{0}+\mathrm{H}_{2} \mathrm{~S} \\
3 \mathrm{Cu}_{5} \mathrm{FeS}_{4}+6 \mathrm{H}^{+}+2 \mathrm{e}^{-} \rightarrow 5 \mathrm{Cu}_{2} \mathrm{~S}+3 \mathrm{H}_{2} \mathrm{~S}+2 \mathrm{Fe}^{2+}
\end{gathered}
$$

The reactions for peak 6 involved the formation of chalcocite, which can be described as follows: ${ }^{34,47}$

$$
\begin{gathered}
\mathrm{Cu}^{2+}+\mathrm{CuS}+2 \mathrm{e}^{-} \rightarrow \mathrm{Cu}_{2} \mathrm{~S} \\
2 \mathrm{CuS}+2 \mathrm{H}^{+}+2 \mathrm{e}^{-} \rightarrow \mathrm{Cu}_{2} \mathrm{~S}+\mathrm{H}_{2} \mathrm{~S}
\end{gathered}
$$

\subsection{Discussions}

Synchrotron X-ray powder diffraction analysis (Fig. 3a) showed that the peaks for bornite underwent massive changes, while those for marmatite remained unchanged in the abiotic system. The main intermediate of bornite dissolution was haycockite $\left(\mathrm{Cu}_{4} \mathrm{Fe}_{5} \mathrm{~S}_{8}\right)$; the peaks for marmatite were always observed in the residues of marmatite and mixed ores, indicating that bornite dissolved faster than marmatite. However, no metal mineralogical phases were obviously detected in the residues for the biotic system (Fig. 3b). Only an elemental sulfur phase was detected, which indicated that the minerals dissolved more completely.

The Raman database used for comparing the obtained spectra is the RRUFF database. ${ }^{48}$ The bands for sphalerite are mainly observed at 299 and $320 \mathrm{~cm}^{-1}$. Elemental sulfur has very strong bands at 154, 220 and $473 \mathrm{~cm}^{-1}$. The bands for jarosite are similar to those of elemental sulfur $\left(154,220\right.$ and $\left.473 \mathrm{~cm}^{-1}\right)$, but bands also exist at 138, 153, 220 and $639 \mathrm{~cm}^{-1}$. The band for chalcocite is mainly found at $213 \mathrm{~cm}^{-1}$, while the bands for covellite are mainly observed at 261 and $470 \mathrm{~cm}^{-1}$ (ESI, Fig. S1†).

The Raman spectra of the dissolution residues are shown in Fig. 3c-d. In the abiotic system, bands for sphalerite were detected, which were consistent with the analytic result of synchrotron radiation. There was a band for chalcocite $\left(213 \mathrm{~cm}^{-1}\right)$; it was speculated that chalcocite may exist in the dissolution residues of bornite and mixed ores $(\mathrm{M}: \mathrm{B}=1: 3)$. The band was also detected at $477 \mathrm{~cm}^{-1}$, which was close to the band for elemental sulfur, indicating that elemental sulfur covered the surface of the residues. In the biotic system, the main bands for the residues were in accordance with those of elemental sulfur and jarosite. The band at $259 \mathrm{~cm}^{-1}$ could be attributed to covellite. This result was consistent with a previous research result. ${ }^{\mathbf{1 6}}$

During the whole dissolution process, the values of $\mathrm{pH}$ in both the biotic and abiotic systems were always maintained at 1.70-1.80. Based on the dynamic monitoring of the daily $\mathrm{pH}$ values and according to eqn (14)-(16), we could calculate the acid consumption during the entire leaching process. The total acid consumption in both the biotic and abiotic systems is shown in Fig. 4a; it can be found that the whole acid consumption increased on increasing the bornite ratio.

$$
\begin{gathered}
\mathrm{pH}_{1}=-\lg \left[\mathrm{H}_{1}^{+}\right] \\
\mathrm{pH}_{2}=-\lg \left[\mathrm{H}_{2}^{+}\right] \\
m=\left(10^{-\mathrm{pH}_{1}}-10^{-\mathrm{pH}_{2}}\right) \times V
\end{gathered}
$$

here, $m$ is the daily acid consumption (mmol), $\mathrm{pH}_{1}$ and $\mathrm{pH}_{2}$ refer to the final $\mathrm{pH}$ values of the previous day and the initial $\mathrm{pH}$ values of the following day, respectively, and $V$ is a constant equal to $100 \mathrm{ml}$.

In the abiotic system, the interactions between bornite and marmatite were more obvious. As mentioned above, the addition of marmatite accelerated the dissolution of bornite, while the addition of bornite impeded the dissolution of marmatite. For the dissolution of bornite, ORP increased gradually on increasing the proportion of marmatite in the mixed ores because of the contributions of the dissolved iron from marmatite (Fig. 4b), thus accelerating the oxidative dissolution process. The dissolution of bornite in the mixed ores was accelerated, thus resulting in a higher cupric ion concentration. A high concentration of $\mathrm{Cu}^{2+}\left(>0.75 \mathrm{~g} \mathrm{~L}^{-1}\right)$ was adsorbed on the unreacted marmatite surface to form a passivation layer mainly 

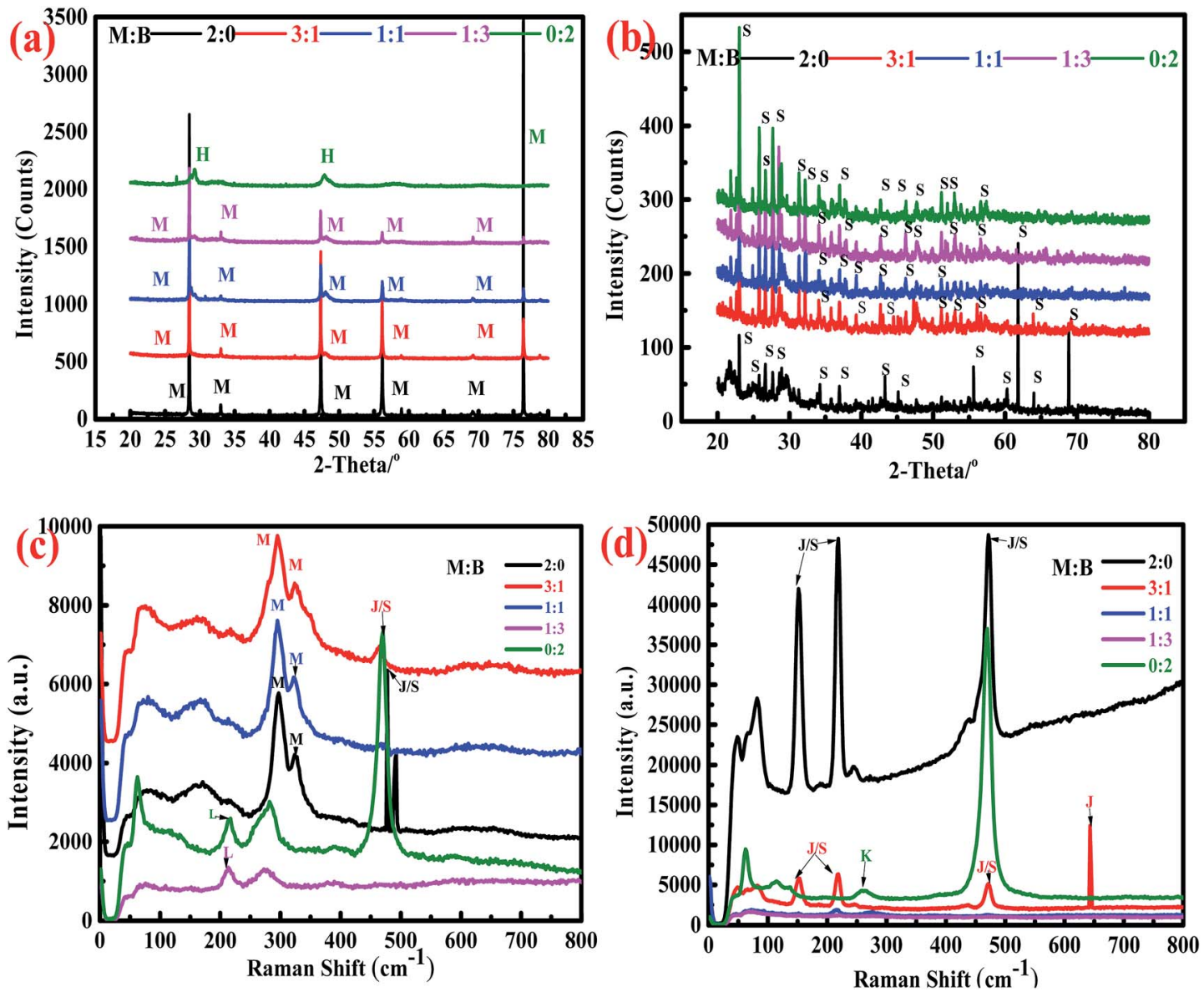

Fig. 3 Synchrotron X-ray powder diffraction analysis and Raman analysis of residues in the abiotic and biotic systems. (a and b) Synchrotron Xray powder diffraction analysis of dissolution residues for (bio)dissolution experiments: (a) dissolution residues in the abiotic system, (b) dissolution residues in the biotic system $\left(\mathrm{H}\right.$ - haycockite, $\mathrm{Cu}_{4} \mathrm{Fe}_{5} \mathrm{~S}_{8} ; \mathrm{L}-$ chalcocite, $\mathrm{Cu}_{2} \mathrm{~S}$; J - jarosite, $\mathrm{KFe}_{3}\left(\mathrm{SO}_{4}\right)_{2}(\mathrm{OH})_{6}$; $\mathrm{K}-\mathrm{covellite}, \mathrm{CuS}$; $\mathrm{M}-$ marmatite, $\left(\mathrm{Zn}_{x} \mathrm{Fe}_{\mathrm{y}}\right) \mathrm{S}$; $\mathrm{S}$ - sulfur, $\mathrm{S}_{8}$ ). (c and d) Raman analysis of dissolution residues for (bio)dissolution experiments: (c) dissolution residues in abiotic system, (d) dissolution residues in biotic system; M (marmatite) and B (bornite).

consisting of $\mathrm{Cu}-\mathrm{S}, \mathrm{Cu}-\mathrm{O}$ and $\mathrm{CuS}_{n}$ species, which reduced the electrochemical reactivity of marmatite and hindered the oxidative dissolution of marmatite. ${ }^{41}$ The lowest cupric ion concentration in the system was $0.8 \mathrm{~g} \mathrm{~L}^{-1}$ on the second day, which inhibited the further dissolution of marmatite according to the above result (Fig. 1f). Furthermore, elemental sulfur and jarosite were formed when the sulfide mineral was oxidized and adhered to the mineral surface, thus hindering the further dissolution of sulfide minerals. ${ }^{24,29}$ Since there were no bacteria in the system, the elemental sulfur hardly oxidized to sulfuric acid. Therefore, the inhibition effect was more obvious than that in the biotic system.

In the biotic system, since the strains used were domesticated, the growth and physiological activity were powerful. As shown in Fig. 4c, the bacterial concentration exceeds $10^{8} \mathrm{~mL}^{-1}$ on the second day and remains above this concentration until the end of the dissolution experiments. The rapid increase in the bacterial concentration accelerated the redox reactions of marmatite and bornite. Therefore, the oxidative dissolution of minerals was accelerated. For the dissolution of bornite, the addition of marmatite increased the concentration of the ferric ions in the solution system (Fig. 4d). The high concentration of ferric ions not only acted as an oxidant for mineral dissolution but also increased the ORP of the system, thus accelerating bornite dissolution. For the dissolution of marmatite, on one hand, the rapid dissolution of bornite caused the concentration of cupric ions to rapidly exceed $1 \mathrm{~g} \mathrm{~L}^{-1}$ on the second day; on the other hand, the elemental sulfur and jarosite generated were attached to the mineral surface. It has been commonly reported that polysulfide is a possible passivating species in metal sulfide leaching. ${ }^{49,50}$ Therefore, the addition of bornite inhibited the dissolution of marmatite. The presence of bacteria attenuated the inhibition effect because the formed elemental sulfur was oxidized into sulfuric acid by the bacteria. However, the biooxidation of elemental sulfur lagged behind the generation process. Hence, the sulfur product layer was still present and became an obstacle for the dissolution of marmatite. ${ }^{42}$

A schematic is shown in Fig. 5 to explain the interaction mechanisms between bornite and marmatite in an acidic environment. $\mathrm{Fe}^{2+}$ dissolved from marmatite and bornite could provide an energy source for the bacterial growth and activity through oxidizing $\mathrm{Fe}^{2+}$ to $\mathrm{Fe}^{3+}$, which produced oxidants of $\mathrm{Fe}^{3+}$ 

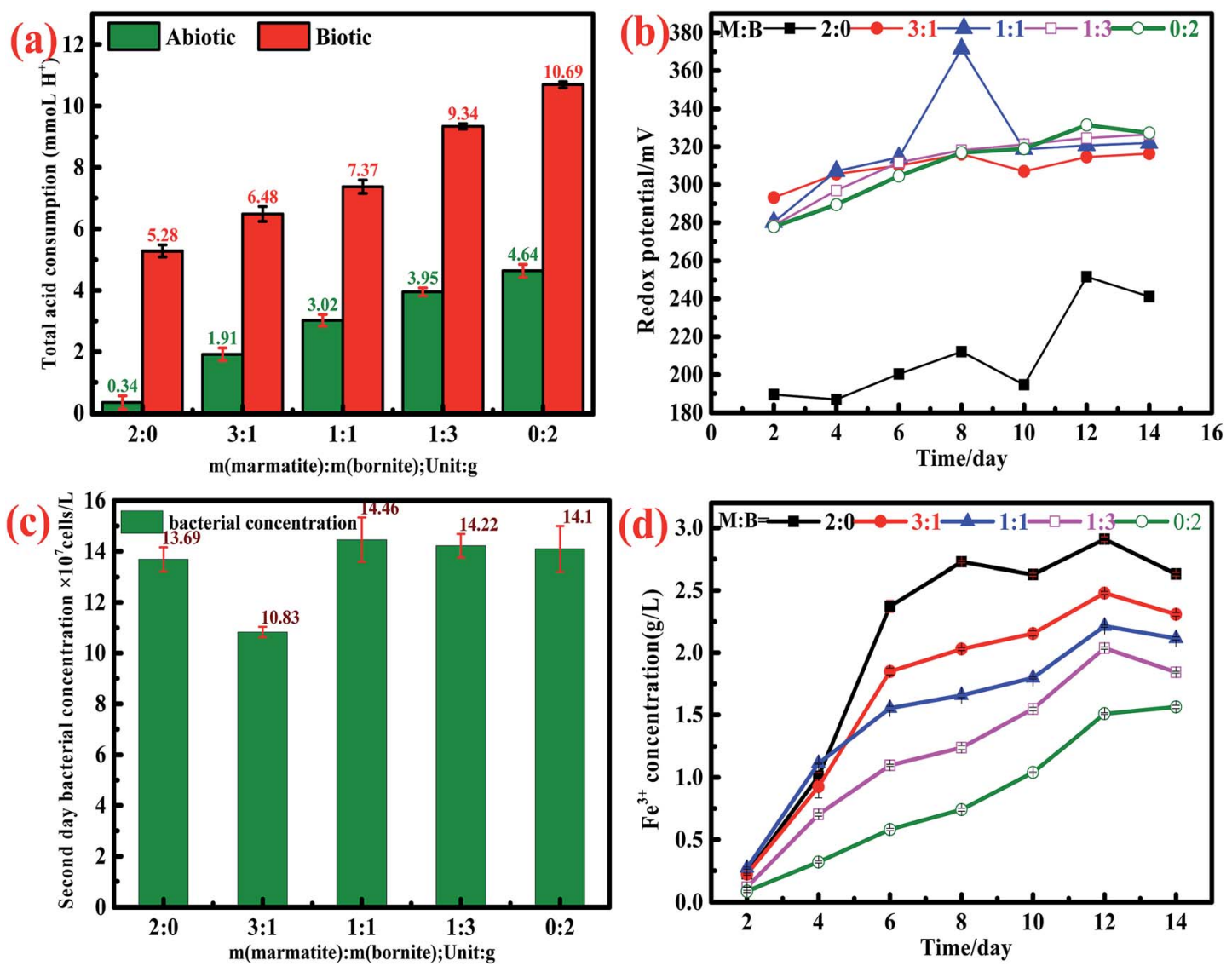

Fig. 4 Characteristics of leachates: (a) total acid consumption in both biotic and abiotic environments. (b) Oxidation reduction potential in the abiotic system. (c) The concentration of bacteria in the biotic system on the $2^{\text {nd }}$ day. (d) Fe $\mathrm{F}^{3+}$ concentration in the biotic system; $\mathrm{M}$ (marmatite) and B (bornite).

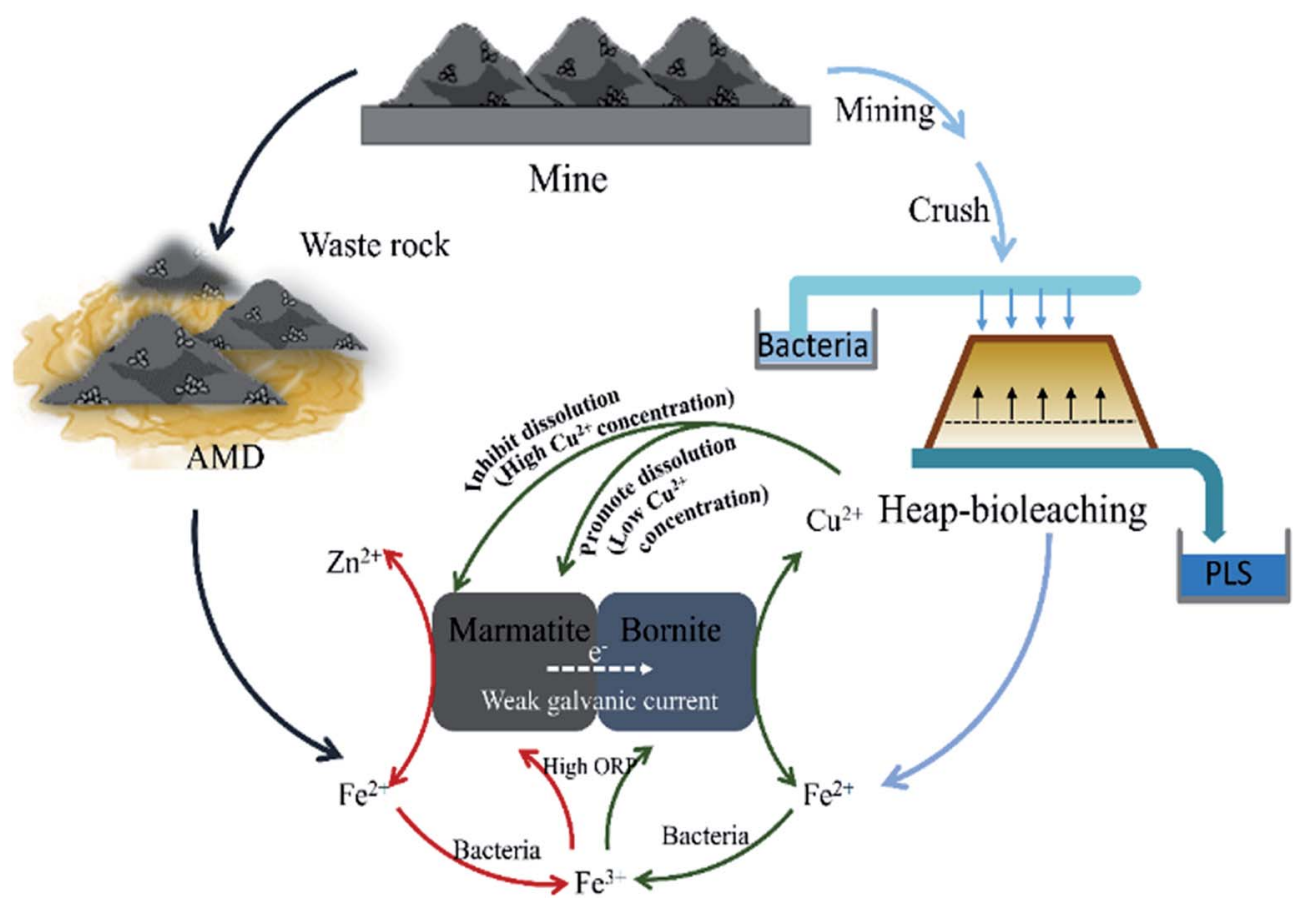

Fig. 5 A model for interpreting the interaction mechanisms between bornite and marmatite in an acidic environment. 
and increased ORP. Hence, the oxidative dissolution process of bornite was accelerated. On the contrary, the dissolution of bornite could produce a high concentration of $\mathrm{Cu}^{2+}\left(>1.0 \mathrm{~g} \mathrm{~L}^{-1}\right)$, thus hindering marmatite dissolution. Bornite intensified marmatite dissolution when the percentage of bornite or $\mathrm{Cu}^{2+}$ concentration (0-0.75 $\left.\mathrm{g} \mathrm{L}^{-1}\right)$ was extremely low, resulting in the occurrence of a synergic dissolution process. In addition, the galvanic current between bornite and marmatite was negligible; thus, its role may be ignored.

\section{Conclusion}

The oxidative dissolution processes of marmatite and bornite were both acid-consuming processes, and bornite dissolution consumed more sulfuric acid. The dissolution of bornite could be accelerated by the addition of marmatite, which produced oxidants of $\mathrm{Fe}^{3+}$ and increased ORP. The acceleration effect in the biotic system was less obvious than that in the abiotic system. The dissolution of marmatite was inhibited by the addition of bornite because a high $\mathrm{Cu}^{2+}$ concentration (higher than $1 \mathrm{~g} \mathrm{~L}^{-1}$ ) could significantly hinder marmatite dissolution. Furthermore, the formation of elemental sulfur or jarosite was also one important cause for hindering marmatite dissolution. This was one reason for the different degrees of inhibition in the abiotic and biotic systems because the bacteria could oxidize the formed elemental sulfur. Theoretically, if the $\mathrm{Cu}^{2+}$ concentration caused by bornite dissolution would have been maintained at a relatively low concentration, the presence of bornite would have accelerated the dissolution of marmatite, thus resulting in a synergistic dissolution process. In addition, the galvanic effect between bornite and marmatite was negligible, and its role may be ignored. The research results can help understand the generation mechanisms of AMD and would also provide a reference for preventing the production of AMD from the source. This work can contribute to understanding the (bio) leaching process of complex ores such as selective and cooperative (bio)leaching. Furthermore, the obtained results would also be useful for studying the interactions of other sulfide minerals in abiotic and/or biotic systems.

\section{Conflicts of interest}

There are no conflicts to declare.

\section{Acknowledgements}

This work was supported by the National Natural Science Foundation of China (51704331), the Young Elite Scientists Sponsorship Program by CAST (2017QNRC001), the InnovationDriven Project of Central South University (2018CX019), as well as the Postgraduate Independent Exploration and Innovation Project of Central South University (2019zzts705). The authors also thank Beamline 4B9A (Beijing Synchrotron Radiation Facility) for providing the experimental facilities.

\section{References}

1 V. P. Evangelou, J. Lab. Clin. Med., 1995, 82, 377-389.

2 D. B. Johnson and K. B. Hallberg, Sci. Total Environ., 2005, 338, 3-14.

3 A. Parbhakar-Fox and B. G. Lottermoser, Miner. Eng., 2015, 82, 107-124.

4 G. S. Simate and S. Ndlovu, J. Environ. Chem. Eng., 2014, 2, 1785-1803.

5 A. Akcil and S. Koldas, J. Cleaner Prod., 2006, 14, 1139-1145.

6 N. Kuyucak, CIM Bull., 2002, 95, 96-102.

7 N. O. Egiebor and O. Ben, Asia-Pac. J. Chem. Eng., 2010, 2, 4762.

8 E. R. Bobicki, Q. Liu, Z. Xu and H. Zeng, Prog. Energy Combust. Sci., 2012, 38, 302-320.

9 F. Anjum, M. Shahid and A. Akcil, Hydrometallurgy, 2012, 117-118, 1-12.

10 M. Chen, Y. Zhang, B. Zhong, Q. Liyou and B. Liang, Ind. Eng. Chem. Res., 2002, 41, 1329-1334.

11 R. A. Davis Jr, A. T. Welty, J. Borrego, J. A. Morales, J. G. Pendon and J. G. Ryan, Environ. Geol., 2000, 39, 11071116.

12 D. E. Rawlings, Annu. Rev. Microbiol., 2002, 56, 65.

13 E. González-Toril, E. Llobet-Brossa, E. O. Casamayor, R. Amann and R. Amils, Ind. Eng. Chem. Res., 2003, 69, 4853.

14 F. S. Martín, W. Kracht and T. Vargas, Miner. Eng., 2018, 117, 127-131.

15 Z. X. Liu, Z. L. Yin, S. F. Xiong, Y. G. Chen and Q. Y. Chen, Hydrometallurgy, 2014, 144-145, 86-90.

16 D. Bevilaqua, O. Garcia and O. H. Tuovinen, Process Biochem., 2010, 45, 101-106.

17 X. Tong, S. Song, J. He, F. Rao and A. Lopez-Valdivieso, Miner. Eng., 2007, 20, 259-263.

18 H. Zhao, X. Gan, J. Wang, L. Tao, W. Qin and G. Qiu, Hydrometallurgy, 2017, 171, 374-386.

19 F. K. Crundwell, Hydrometallurgy, 1988, 21, 155-190.

20 S. Y. Shi, Z. H. Fang and J. R. Ni, Bioelectrochemistry, 2006, 68, 113-118.

21 S. Y. Shi, Z. H. Fang and J. R. Ni, Process Biochem., 2006, 41, 438-446.

22 J. R. Ban, G. U. Guo-Hua and H. U. Ke-Ting, Trans. Nonferrous Met. Soc. China, 2013, 23, 494-500.

23 H. Zhao, J. Wang, X. Gan, X. Zheng, L. Tao, M. Hu, Y. Li, W. Qin and G. Qiu, Bioresour. Technol., 2015, 194, 28-35.

24 H. Zhao, J. Wang, M. Hu, W. Qin, Y. Zhang and G. Qiu, Bioresour. Technol., 2013, 149, 71-76.

25 R. G. Acres, S. L. Harmer and D. A. Beattie, Int. J. Miner. Process., 2010, 94, 43-51.

26 A. Saavedra, J. V. García-Meza, E. Cortón and I. González, Electrochim. Acta, 2018, 265, 569-576.

27 R. Liao, J. Wang, H. B. Zhao, X. X. Wang, X. T. Huang and M. X. Hong, Solid State Phenom., 2017, 262, 168-171.

28 D. Bevilaqua, H. A. Acciari, F. A. Arena, A. V. Benedetti, C. S. Fugivara, G. T. Filho and O. G. Júnior, Miner. Eng., 2009, 22, 254-262.

29 S.-Y. Shi and Z.-H. Fang, Hydrometallurgy, 2004, 75, 1-10. 
30 J. Castillo, R. Pérez-López, M. A. Caraballo, J. M. Nieto, M. Martins, M. C. Costa, M. Olías, J. C. Cerón and R. Tucoulou, Sci. Total Environ., 2012, 423, 176-184.

31 A. Voegelin, O. Jacquat, S. Pfister, K. Barmettler, A. C. Scheinost and R. Kretzschmar, Environ. Sci. Technol, 2011, 45, 255-261.

32 H.-b. Zhao, M.-h. Hu, Y.-n. Li, S. Zhu, W.-q. Qin, G.-z. Qiu and J. Wang, Trans. Nonferrous Met. Soc. China, 2015, 25, 303-313.

33 A. N. Buckley, I. C. Hamilton and R. Woods, J. Appl. Electrochem., 1984, 14, 63-74.

34 G. Gu, K. Hu, X. Zhang, X. Xiong and H. Yang, Electrochim. Acta, 2013, 103, 50-57.

35 T. Rohwerder, T. Gehrke, K. Kinzler and W. Sand, Appl. Microbiol. Biotechnol., 2003, 63, 239.

36 T. J. Veasey and B. A. Wills, Miner. Eng., 1991, 4, 747-752.

37 Y. Zhang, G. Zhao, X. Lv, Y. Tian, L. Yang, G. Zou, H. Hou, H. Zhao and X. Ji, ACS Appl. Mater. Interfaces, 2019, 11, 6154-6165.

38 X. Wang, R. Liao, H. Zhao, M. Hong, X. Huang, H. Peng, W. Wen, W. Qin, G. Qiu, C. Huang and J. Wang, Hydrometallurgy, 2018, 176, 9-16.

39 A. D. Bas, W. Zhang, E. Ghali and Y. Choi, Hydrometallurgy, 2015, 158, 1-9.
40 L. G. Saywell and B. B. Cunningham, Ind. Eng. Chem., Anal. Ed., 1937, 9, 67-69.

41 X. Meng, H. Zhao, M. Sun, Y. Zhang, Y. Zhang, X. Lv, H. Kim, M. Vainshtein, S. Wang and G. Qiu, Sci. Total Environ., 2019, 675, 213-223.

42 Z. Lan, Y. Hu and W. Qin, Miner. Eng., 2009, 22, 10-13.

43 L. I. Hong-Xu, G. Z. Qiu, H. U. Yue-Hua, D. Q. Cang and D. Z. Wang, Trans. Nonferrous Met. Soc. China, 2006, 16, 1240-1245.

44 C.-L. Liang, J.-L. Xia, Y. Yang, Z.-Y. Nie, X.-J. Zhao, L. Zheng, C.-Y. Ma and Y.-D. Zhao, Hydrometallurgy, 2011, 107, 13-21.

45 M. Sauber and D. G. Dixon, Hydrometallurgy, 2011, 110, 1-12. 46 A. E. Elsherief, Miner. Eng., 2002, 15, 215-223.

47 E. M. Arce and I. González, Int. J. Miner. Process., 2002, 67, 17-28.

48 D. T. U. o. Arizona, The RRUFF Project website containing an integrated database of Raman spectra for minerals, 2018.

49 H. Zhao, Y. Zhang, X. Zhang, L. Qian, M. Sun, Y. Yang, Y. Zhang, J. Wang, H. Kim and G. Qiu, Miner. Eng., 2019, 136, 140-154.

50 M. Khoshkhoo, M. Dopson, A. Shchukarev and Å. Sandström, Hydrometallurgy, 2014, 149, 220-227. 